\title{
Individualism, Uncertainty Avoidance, and Earnings Momentum in International Markets
}

\author{
PAUL DOU,* JAMES HUNTON $\uparrow$, CAMERON TRUONG,* AND MADHU \\ VEERARAGHAVAN
}

\begin{abstract}
*Department of Accounting and Finance, Monash University, Clayton Campus, Melbourne, Australia. $†$ Accountancy Department, Bentley University and Rotterdam School of Management, Erasmus University. $\ddagger$ Department of Accounting and Finance, Monash University, Clayton Campus, Melbourne, Australia, and Centre Associate, Australian Centre for Financial Studies, Australia.
\end{abstract}

We are grateful to Sophia Berndt, Robert Bianchi, Graham Bornholt, Andy Chui, Michael Dempsey, Binh Do, Michael Drew, David Emanuel, Laurence Irlicht, Farshid Navissi, Axel Schulz, Mike Shields, David Smith, K.C. John Wei, Ari Yegezel, and seminar participants at Monash University (Finance Brown Bag Seminar Series and the Accounting and Finance Behavioural Research Group), RMIT University and Griffith University for helpful comments and suggestions. 


\title{
Individualism, Uncertainty Avoidance, and Earnings Momentum in International Markets
}

\begin{abstract}
The literature shows that price and earnings momentum returns cannot be fully explained by risk-based theories. In an attempt to better understand the price momentum anomaly, Chui et al. [2010] document that the cultural factor of "individualism" influences price momentum returns, but that the cultural factor of "uncertainty avoidance" does not. The current study extends Chui et al. [2010] by examining the influence of individualism and uncertainty avoidance on earnings momentum profits, as theory suggests that unique characteristics associated with earnings momentum, relative to price momentum, give rise to significant effects for both these cultural factors. Using data from 41 countries, we show that the level of individualism in a country is positively associated with earnings momentum profits and that the level of uncertainty avoidance is negatively associated with earnings momentum profits. This study contributes to the ongoing quest to better understand the earnings momentum phenomenon.
\end{abstract}

Keywords: post-earnings announcement drift, individualism, earnings momentum, uncertainty avoidance, culture 


\section{Introduction}

This paper investigates the extent to which the earnings momentum phenomenon ${ }^{1}$ is influenced by two cultural factors: individualism ${ }^{2}$ and uncertainty avoidance $^{3}$ (Hofstede [1980], [2001]). Results from Chui et al. [2010] suggest that countries scoring higher on the Hofstede [2001] individualism index tend to produce greater price momentum returns; however, these authors find no significant association between uncertainty avoidance and price momentum returns, and they do not examine earnings momentum. They indicate that

\footnotetext{
${ }^{1}$ Fama [1998] states that two robust and persistent anomalies that challenge the market efficiency hypothesis are post-earnings announcement drift, documented by Ball and Brown [1968], and short-term continuation of returns, documented by Jegadeesh and Titman [1993]. A price momentum strategy involves buying past winner stocks and selling past loser stocks, based on historical stock price performance, as evidence suggests that the stock price of past winners will drift upward and the stock price of past losers will drift downward over an intermediate horizon (3-6 months). An earnings momentum strategy involves buying past winner stocks and selling past loser stocks, based on whether the firms report unexpectedly high earnings or unexpectedly low earnings, as evidence indicates that firms with unexpectedly high earnings will continue to outperform firms with unexpectedly low earnings. Chordia and Shivakumar [2006] suggest that such superior performance lasts for about 9 months after earnings announcements.
}

\footnotetext{
${ }^{2}$ Individualism and collectivism reflect two ends of a spectrum; both of these cultural perspectives involve the basic source of one's self-image or self-esteem (Hofstede [2001]). In an individualistic culture, people tend to see themselves as being independent and autonomous, whereas people in a collectivist culture tend to view themselves as being interdependent and connected to others in the society (Markus and Kitayama [1991]).

${ }^{3}$ Uncertainty avoidance refers to actions that individuals in a society take to cope with feelings of threat emanating from the unknown. On one end of the spectrum, individuals in high uncertainty avoidance cultures react relatively quickly when their threat-related anxiety deviates from their comfort zone, the variance of which is quite narrow. On the other end of the spectrum, individuals in low uncertainty avoidance cultures are more tolerant of ambiguity, thus they react relatively slowly when their threat-related anxiety deviates from their comfort zone, the variance of which is quite wide (Hofstede [2001]).
} 
the significant relationship between price momentum and individualism is obtained because investors in an individualistic culture, relative to collectivist culture, are less willing to update their prior beliefs in light of new information (underreaction to public information and overreaction to private information arising from self-confidence and self-attribution).

The association between price momentum returns and uncertainty avoidance is not significant, likely because price momentum arises from a broad set of economic information (e.g., interest rate trends, currency translation fluctuation, consumer purchasing sentiment, price inflation movement, and so on) that can shift in direction and velocity. The diverse set of inputs associated with price momentum makes it difficult for individuals to pinpoint when uncertainty crosses the threshold at which avoidance action (i.e., selling the stock) becomes necessary; thus, the relationship between uncertainty avoidance and price momentum is too noisy to detect a significant correlation.

We propose that earnings momentum is significantly related to individualism for the same underlying reason as price momentum (underreaction to public information and overreaction to private information). Additionally, we hypothesize a relationship between uncertainty avoidance and earnings momentum, because any surprise emanating from earnings announcements can be readily assessed, and individuals in a high (relative to low) uncertainty-avoidance culture are likely to update their beliefs and trade more quickly to absorb earnings surprise into stock prices. Conversely, we suggest that individuals in a low 
uncertainty-avoidance culture underreact to earnings surprises, thus contributing to the earnings momentum phenomenon.

Using data from 41 countries for the period 1995-2008, we show that both individualism and uncertainty avoidance are significantly correlated with earnings momentum. We incorporate the cross-country variables used in Chui et al. [2010], including proxies for information uncertainty suggested by Zhang [2006], market development and institutional quality variables, and proxies for transaction costs and information flow, along with macroeconomic variables (such as GDP and inflation), as in Griffin et al. [2003]. Although earnings momentum profits are significantly correlated with a prevalence of insider trading and the inflation rate, the inclusion of such control variables in our analysis does not affect the explanatory power of individualism and uncertainty avoidance for earnings momentum profits.

This study contributes to the literature in two ways. First, to our knowledge, this is the first study to examine the association between cultural differences and earnings momentum profits. Hong et al. [2003] examine variation in international earnings momentum profits and advance a link between momentum and the information dissemination mechanism within a country; ${ }^{4}$ however, these authors acknowledge that their evidence is limited by the nature of

\footnotetext{
${ }^{4}$ Hong et al. [2003, p25] state that "our evidence is limited by the nature of data and is by no means conclusive. We only have information on 11 countries and there are many other potential market characteristics that could help explain the momentum effects. For example, cultural and institutional differences across Asian and European countries might offer a competing explanation."
} 
the available data. Expanding on this finding, we not only include additional equity markets in our sample, but more importantly, we investigate the role of cultural differences as a possible explanation for the variation in international earnings momentum profits. In a similar vein, Hirshleifer and Teoh [2009, p. 1067] state “..ppsychological forces influence individual and group behavior in many contexts. So we argue that to capture important features of accounting, we must go beyond the assumption of perfect rationality." Our findings show that innate differences in behavior among international investors explain how such investors respond to accounting earnings, and hence help to explain the cross-section of the earnings momentum anomaly in an international setting.

Second, this study contributes to the ongoing investigation on whether and how price momentum and earnings momentum are interrelated. Chan et al. [1996] acknowledge that the momentum anomaly remains "a major unresolved puzzle" and argue that earnings momentum cannot be subsumed by price momentum because each of these factors underreacts to a different set of information..$^{5}$ In a similar vein, Fama [1998] states that the two robust and persistent anomalies that challenge the market efficiency hypothesis are the post-earnings announcement drift documented by Ball and Brown [1968] and short-term

\footnotetext{
${ }^{5}$ Chan et al. [1996] argue that price momentum is a result of investor under-reaction to broad economic information, and earnings momentum is a result of investor under-reaction to company-specific earnings information. These authors also document that the price momentum effect is stronger and longer-lived than the earnings momentum effect.
} 
continuation of returns documented by Jegadeesh and Titman [1993]. Consistent with the argument presented by Chan et al. [1996], results from Chordia and Shivakumar [2002] and Avramov and Chordia [2006] indicate that price momentum is related to broad economic fundamentals and suggest that firm-specific characteristics such as earnings surprises cannot explain price momentum. However, Chordia and Shivakumar [2006] indicate that price momentum is a manifestation of earnings momentum. In a recent paper, Leippold and Lohre [2008] support the findings of Chordia and Shivakumar [2006] for the US market; however, these authors show that the association between price and earnings momentum does not apply to every European country (16 sample countries) investigated in their paper. Results from the present study indicate that earnings and price momentum are related, as both are influenced by the degree of individualism in a culture; however, there is at least one unique underlying cultural factor, uncertainty avoidance, separating the two momentum phenomena.

This paper proceeds as follows. In Section 2, we review the literature and develop our hypotheses. Section 3 sets forth our data, and in Section 4 we discuss our methodology and report initial results on earnings momentum profits for each country in our sample. Section 5 reports regression results for the relation between cultural variables and earnings momentum profits. Finally, Section 6 sets forth our conclusion. 


\section{Background and Hypotheses}

\subsection{EARNINGS MOMENTUM}

Earnings momentum, also referred to as post-earnings announcement drift (PEAD), is one of the best-documented and most resilient capital-markets anomalies. The literature, beginning with Ball and Brown [1968], Jones and Litzenberger [1970], Latane et al. [1970], Joy et al. [1977], and Latane and Jones [1979], employing different samples and methods, confirms PEAD. Increased interest in and a demand for more rigorous examination of PEAD led to larger-scale studies, such as Foster et al. [1984], Freeman and Tse [1989], Bernard and Thomas [1989, 1990], and Chan et al. [1996]. More recent research, such as Johnson and Schwartz [2001], Ertimur et al. [2003], Liang [2003], Francis et al. [2004], Mendenhall [2004], Narayanamoorthy [2004], Chordia and Shivakumar [2006], Livnat and Mendenhall [2006], Jegadeesh and Livnat [2006], and Doyle et al. [2006] continues to generate evidence of a delayed response to the information contained in earnings announcements. Brennan [1991, p. 70] calls PEAD a "most severe challenge to financial theorists," while Fama [1998, p. 286] refers to it as "the granddaddy of all under-reaction events," and Livnat and Mendenhall [2006, p. 181] affirm that PEAD is "the best-documented and most-resilient capital markets anomaly."

Bernard and Thomas [1990] test PEAD using a diverse array of robustness risk adjustment procedures, such as controlling for common risk factors used in tests of the 
Arbitrage-Pricing Theory. These authors conclude that their evidence is not consistent with risk mismeasurement; rather, their findings indicate a delayed price response. In a comprehensive review of the literature, Kothari [2001] shows that PEAD has survived rigorous testing over more than 30 years and cannot be fully explained by other documented anomalies. ${ }^{6}$ Other explanations of PEAD include methodological shortcomings (e.g., Jacob et al. [2000]) and risk mismeasurement (e.g., Ball et al. [1993]). Liang [2003] documents that attempts to explain PEAD as compensation for risk or as flaws in research design are unsuccessful. Liang [2003] concludes that drift is a pricing anomaly and that the bulk of the evidence challenges the traditional view that prices reflect all available information. In sum, it appears that the conclusion that PEAD is a delayed response to earnings information represents the predominant belief among researchers. ${ }^{7}$

International evidence on the profitability of employing an earnings momentum strategy is relatively scant. Studies investigating PEAD outside the US include Hew et al.

\footnotetext{
${ }^{6}$ Researchers hypothesize that earnings surprises should cause gradual, rather than immediate, price adjustments because the opinions of those best able to assess the surprises (market professionals) would be gradually disseminated to the general investing public. Daniel et al. [1998] and Barberis et al. [1998] offer behavioral explanations for why investors might under-react to new information.

${ }^{7}$ This market inefficiency appears to be caused by investors' inability to fully incorporate future predictability of earnings time series, either because they use a naive expectation model (Bernard and Thomas [1990]), or because they underestimate serial correlation of seasonal differences (Ball and Bartov [1996]), or because they fail to incorporate inflation into their estimations (Chordia and Shivakumar [2006]).
} 
[1996], ${ }^{8}$ Booth et al. [1996], Mande and Kwak [1996], Hong et al. [2003], Liu et al. [2003], and Truong [2009]. Hong et al. [2003] find that earnings momentum strategies based on analyst-forecast revisions generate significant profits in Australia, Canada, France, Germany, Hong Kong, and the United Kingdom, but not in Japan, Korea, Malaysia, Singapore, or Taiwan. In the first set of countries, returns to zero-investment strategies based on top- and bottom-quintile portfolios average close to $1 \%$ per month over the succeeding 3 to 6 months. In the second set of countries, returns to earnings momentum strategies are also generally positive, but are not economically or statistically significant.

\subsection{BEHAVIORAL EXPLANATIONS FOR THE MOMENTUM PHENOMENON}

The widely documented phenomenon that investors overreact or underreact to new information has motivated a large and growing body of research in behavioral finance that investigates the financial markets and their participants from a psychological perspective (e.g., Daniel et al. [1998], Barberis et al. [1998], and Hong and Stein [1999]). Daniel et al. [1998] propose that the momentum/price drift effect is a result of underreaction and overreaction by over-confident and self-attributing investors, who tend to overweight their

\footnotetext{
${ }^{8} \mathrm{Hew}$ et al. [1996] provide preliminary evidence of post-earnings announcement drift in the UK. Booth et al. [1996] document evidence of post-earnings announcement drift in Germany. Mande and Kwak [1996] find postearnings announcement drift in the Japanese market. Hong et al. [2003] examine earnings momentum in several international markets. Liu et al. [2003] reconfirm the existence of post-earnings announcement drift in the UK by using several measures of earnings surprise and Truong [2009] shows that the post-earnings announcement drift exists in New Zealand and that the magnitude of the drift is an increasing function of arbitrage risk.
} 
prior beliefs about a stock's value and, hence, overreact to their own private information and underreact to public information, such as earnings news. These authors' model relies on overconfidence and self-attribution bias, and their theory is consistent with the view that people overestimate their own abilities, perceive themselves more favorably than they are viewed by others, and attribute success to their own abilities and failure to exogenous factors.

Daniel et al. [1998] state that the confidence of the investor grows when public information is in line with the investor's information, but does not fall commensurately when public information contradicts the investor's information. These authors show that market underreaction occurs when investors are overconfident about their private information and argue that their model can potentially explain price momentum as well as short-run earnings drifts. The accounting literature also attributes PEAD to information processing biases. Although, studies such as Freeman and Tse [1989], Bernard and Thomas [1989] and [1990], Abarbanell and Bernard [1992], Bartov [1992], and Ball and Bartov [1996], advance the notion that drift is due to market underreaction to a current earnings surprise, but that the cause of this underreaction is unclear. Liang [2003] provides a link between drift and investors' non-Bayesian behavior and hypothesizes that when investors have more heterogeneous information, this leads to more drift. Note that non-Bayesian investors can be defined as those investors who overweight their heterogeneous information and underweight public earnings announcements. Liang [2003] shows that investor overconfidence about 
private information and the reliability of earnings information explains drift; hence, drift represents market inefficiencies arising from imperfect information-processing behavior by investors-i.e., investors' non-Bayesian behaviors lead to drift.

Barberis et al. [1998] propose a model of investor sentiment that addresses how investors form beliefs. This model encompasses two judgment biases - the representativeness bias of Kahneman and Tversky [1974] and the conservatism bias of Edwards [1968]. The representativeness bias reflects the "...tendency of experimental subjects to view events as typical or representative of some specific class and to ignore the laws of probability in the process" (Barberis et al. [1998], p. 2). The conservatism bias reflects the slowness with which investors are willing to change their initial impressions in light of new evidence. These authors show that the conservatism bias leads to insufficient consideration of new earnings information, because investors believe that the new number contains a large temporary component, and they still adhere at least partially to their prior estimates. As a result, investors adjust their valuations only partially, which results in market underreaction to earnings news. Hong and Stein [1999] examine the risk tolerance of momentum traders and document that as risk tolerance increases, momentum traders respond more aggressively to past price changes and, therefore, overreact, resulting in momentum profits.

Motivated by Daniel et al. [1998], Chui et al. [2010] examine the extent to which the price momentum effect is generated by behavioral biases. Specifically, these authors examine 
whether price momentum profits are greater in countries where investors are likely to exhibit the psychological biases documented in the behavioral finance literature. They posit that individualism can be used to proxy overconfidence and self-attribution bias, and show that the level of individualism in a country is positively associated with the magnitude of international price momentum profits. They also associate another cultural variable, uncertainty avoidance, with price momentum returns, but find no significant effect.

Given this backdrop, we extend the work of Chui et al. [2010] by examining the association of "individualism" with earnings momentum profits. We also examine the relationship between uncertainty avoidance and earnings momentum profits, and by so doing, we provide insight into the associations between several behavioral biases and earnings momentum profits. Our paper is a first step in empirically linking individualism, uncertainty avoidance, and earnings momentum profits. The underlying reasoning for addressing this empirical relationship is discussed below.

\subsection{INDIVIDUALISM}

"Individualism" here refers to the degree to which people tend to hold an independent rather than an interdependent self-image or sense of self-esteem (Hofstede [2001]). The opposite of individualism is collectivism. Markus and Kitayama [1991] and Heine et al. [1999] argue that people in individualistic cultures tend to overestimate their own abilities. In addition, Markus and Kitayama [1991] and Kagitcibasi [1997] suggest that the tendency to 
maintain and promote self-esteem in individualistic cultures results in pervasive self-attribution bias as well as overconfidence. Stulz and Williamson [2003] document that differences in culture cannot be ignored when attempting to understand why investor protection differs across countries. These authors state that "a more direct investigation is called for to determine whether there is evidence that culture matters for finance beyond its relation with legal origins" [2003, p. 314]. In a recent paper, Chui et al. [2010] show that individualism is positively associated with trading volume and volatility, ${ }^{9}$ and is strongly related to the magnitude of momentum profits. Chui et al. [2010] is the first study in the finance literature to use the Hofstede individualism index.

In the accounting literature, Chow et al. [1991], Chow et al. [1994], and Kachelmeier and Shehata [1997] incorporate the Hofstede individualism index. Chow et al. [1991] investigate the effects of national culture on manufacturing performance. Specifically, they examine whether the management control systems of Asian manufacturing firms can be employed by non-Asian firms to improve their manufacturing performance. Chow et al. [1994] study how national culture affects potential employees' self-selection of management

\footnotetext{
${ }^{9}$ To provide further support for the notion that investors in individualistic cultures are overconfident, Chui et al. [2010] show that individualism is correlated with trading volume and volatility. Gervais and Odean [2001] develop a model in which a trader initially does not know his/her ability, but learns about his/her ability through experience. In their model, these authors show that a trader's level of over-confidence changes dynamically with the trader's successes and failures. They also show that an over-confident trader trades aggressively, which increases expected trading volume. They demonstrate that greater profits generated by traders leads to overconfidence.
} 
control components. These authors use the widely applied taxonomy of work-related national culture advanced by Hofstede [1980, 1991] and test their hypotheses on Japanese and US samples. Kachelmeier and Shehata [1997] investigate whether the demand for and effectiveness of audit-based monitoring is influenced by differing cultural values across societies. They focus on the Hofstede [1991] individualism versus collectivism construct, which they argue is relevant to accounting settings. These authors report that audit-based monitoring is less effective and less demanded in Hong Kong and the People's Republic of China than in Canada, and that this difference arises in a setting with a low degree of anonymity.

\subsection{UNCERTAINTY AVOIDANCE}

Hofstede [2001] states that uncertainty avoidance measures the extent to which a culture programs its members to feel either uncomfortable or comfortable in unstructured situations, which are defined as novel, unknown, surprising, or different from usual. The main underlying dimension is individual tolerance for uncertainty (ambiguity), which in identical situations leads some individuals to feel more pressed for action than others. The term "uncertainty avoidance" was introduced in Cyert and March [1963], who state that people in uncertainty-avoiding cultures emphasize short-run reaction to short-run feedback rather than anticipation of long-run uncertainty; such people solve pressing problems rather than develop long-run strategies. The opposite holds for people with high tolerance for 
uncertainty. Hofstede [2001] further documents that people with low uncertainty avoidance often exhibit a low sense of urgency in ambiguous, surprising, or unstructured situations, whereas people in uncertainty-avoiding cultures feel more anxious in such situations, and therefore tend to take immediate action to reduce the level of ambiguity. ${ }^{10}$

\subsection{HYPOTHESIS DEVELOPMENT}

\section{Individualism and Earnings Momentum}

Daniel et al. [1998] state that informed investors are subject to overconfidence and self-attribution biases. Overconfidence bias leads informed investors to overweight the precision of their private signals, and self-attribution causes them to underweight public signals about a stock's value. This overreaction to private signals and underreaction to public signals produces short-term continuation of returns. Relying on this theory and using individualism as a proxy for overconfidence, Chui et al. [2010] document a positive relationship between price momentum returns and individualism. Relying on the same reasoning, we also expect that individualism is associated with higher earnings momentum profits, as follows:

\footnotetext{
${ }^{10}$ It is important to distinguish uncertainty avoidance from risk tolerance. Hong and Stein [1999] set forth a model that predicts that overreaction and momentum profits are more pronounced if the risk tolerance of momentum traders is higher. While high risk tolerance and low uncertainty avoidance predict similar results, we argue that uncertainty avoidance is not a proxy for risk tolerance because the former reflects a micro-level individual trait, whereas the latter reflects a macro-level cultural factor; further, when risk tolerance and uncertainty avoidance are in conflict, it is unclear which one will dominate risky decisions.
} 
H1: Individualism is positively related to the magnitude of earnings momentum profits.

\section{Uncertainty Avoidance and Earnings Momentum}

The association between price momentum returns and uncertainty avoidance is likely non-significant in the Chui et al. [2010] study because price momentum arises from a noisy range of macroeconomic information, such as interest rates, currency translations, consumer sentiments and price inflation. Such a diverse set of inputs makes it difficult for individuals to recognize when uncertainty-avoidance action is necessary; thus, both high and low uncertainty-avoidance cultures are fairly slow to react to public information, which exacerbates the price momentum phenomenon, but does not allow for differentiation across the spectrum of uncertainty-avoidance cultures. We posit a significant relationship between uncertainty avoidance and earnings momentum because earnings surprises are less noisy than general economic indicators, hence, the direction and magnitude of such surprises can be fairly quickly impounded into an investor's decision-making processes. As a result, investors in a high, relative to low, uncertainty-avoidance culture are likely to update their beliefs and trade more quickly to reduce the anxiety associated with earnings surprise. Hence, we hypothesize that people in low uncertainty-avoidance countries are likely to underreact to large earnings surprises, leading to higher earnings momentum profits:

H2: Uncertainty avoidance is negatively related to the magnitude of earnings momentum profits. 


\section{Data Description and Summary Statistics}

\subsection{THE HOFSTEDE INDIVIDUALISM INDEX AND UNCERTAINTY-AVOIDANCE}

\section{INDEX}

Data for this study are obtained from several sources. The Hofstede individualism index (IDV) and uncertainty-avoidance index (UAI) are obtained from the Geert Hofstede psychological survey of IBM employee values, conducted twice (1968 and 1972) in 72 countries. Of these 72 countries, 40 had more than 50 respondents each. IDV is calculated from country mean scores on 14 questions about employee attitudes toward their own work and private lives. UAI is derived from country mean scores or percentages on three survey questions that address rule orientation, employment stability, and stress.

\subsection{STOCK RETURNS AND EARNINGS ANNOUNCEMENTS}

We obtain stock return data for all markets, with the exception of the US, from Datastream International. We obtain stock return data for the US from CRSP (Center for Research in Security Prices). We obtain earnings data from I/B/E/S (Institutional Brokers' Estimate System). Our initial sample contains stock and earnings data from 51 markets for the sample period January 1995 through December 2008. To arrive at our final sample, we apply several filters to our data. First, companies must be listed on a major exchange(s) in their home country; thus, we exclude cross-listed foreign stocks. Second, companies must be 
represented in both the Datastream and $\mathrm{I} / \mathrm{B} / \mathrm{E} / \mathrm{S}$ databases for international markets and in the

CRSP and I/B/E/S databases for the US market.

Studies have noted that the quality of international stock market data, especially in emerging markets, is not as good as for US data (Hong et al. [2003], Chui et al. [2010]). We face this same problem with both Datastream and I/B/E/S data, where we observe cases of daily returns exceeding $10,000 \%$, and earnings forecast revisions that are greater than 50times current stock prices. To mitigate this problem, we apply several methods to screen out outlier observations. For returns data, we set returns that are larger (less) than $100 \%(-95 \%)$ equal to $100 \%(-95 \%)$.

Following Hong et al. [2003] and Chui et al. [2010], we eliminate stock prices that are less than one, denoted in local currency, for each country in each month, along with earnings announcements with the absolute value of earnings forecast revisions greater than 50 times the current stock price. This procedure helps to filter out all suspicious stock returns and earnings announcement numbers. In addition, this procedure alleviates potential illiquidity problems associated with low-priced or extremely small stocks. To ensure that we have a reasonable number of stocks and earnings announcements in each country's earnings momentum portfolio, we eliminate those countries that have less than 50 stocks or 100 
earnings announcements in our I/B/E/S sample. ${ }^{11}$ We also require that each country have a corresponding IDV and UAI. Application of these criteria results in a final sample of 41 countries and approximately 30,000 firms. Following Chui et al. [2010], we include variables that may determine the cross-country variation of earnings-momentum profits. These variables are designed to explain earnings momentum from the behavioral, financial market development, market integrity, and macroeconomic perspectives. Sources and definitions of these variables are provided in Appendix 1.

Table 1 reports descriptive statistics for each country along with scores on IDV and UAI in the second and third columns, respectively. Column 5 reports the original number of stocks with prices greater than one, denoted in local currency, as obtained from Datastream and CRSP. Columns 6, 7, and 8, show the number of firms, announcements, and analyst forecasts, respectively, in the combined I/B/E/S and Datastream (CRSP for US) sample. In columns 9, 10, and 11, we report the final number of qualifying firms, announcements, and analyst forecasts, respectively, in our combined sample, after applying the screening methods described above. Our final sample includes 30,383 stocks, 167,901 earnings announcements, and 1,327,158 analyst forecasts for the period January 1995 through December 2008.

\footnotetext{
${ }^{11}$ Chui et al. [2010] use 30 stocks as a filtering rule for the sample used in their study, which groups stocks into three momentum portfolios. To ensure each portfolio has a reasonable number of stocks, our study uses 50 stocks as a threshold because we construct five earnings-momentum portfolios for each country.
} 
Table 2 reports Spearman rank correlations for all explanatory variables used in this study. Strong correlations (Spearman Score > 0.5) are shown in bold. We find no strong correlations between IDV and UAI. The table shows strong positive correlation between market size and market volume, between political risk and corruption, and between GDP growth and transaction costs.

\section{Methodology and Findings}

We use the 1-year-ahead (FY1) earnings forecast revision to calculate earnings momentum. Researchers have also used two other measures of earnings surprises: the most recent standardized unexpected earnings (SUE), and the cumulative abnormal stock return around the most recent earnings announcement date (ABR). However, Hong et al. [2003] document that the use of data related to past earnings announcements (SUE or ABR) is problematic in international settings, where firms typically report earnings on an annual basis.

Expectation models (such as SUE) for annual earnings are extremely noisy, whereas time-series models (such as ABR) for expected earnings using annual data have little power. Therefore, if we rank stocks on the basis of their most recent SUE or ABR, the information on earnings surprises could be quite stale. Johnson and Schwartz [2001] show that the drift based on the time-series model of unexpected earnings is largely eliminated in the 1991-1997 period. 
A related set of papers uses analyst forecasts as the benchmark for earnings surprises.

Using Valueline forecasts, Abarbanell and Bernard [1992] report an 8\% hedge return between the top and bottom deciles of earnings surprises over the year following the earnings announcement, noting that this result is quite comparable to the existing evidence, which uses a time-series model as the surprise benchmark. Chan et al. [1996] find that in the US momentum profits based on revisions in analyst forecasts $(9.7 \%$ over the first year after portfolio formation) are higher than those based on SUE (7.5\%) or ABR (8.3\%). By defining the surprise relative to an analyst forecast rather than a time-series model of expected earnings, Doyle et al. [2006] document returns subsequent to earnings announcements that are much larger and that persist for much longer than anything shown in previous studies.

We implement the following earnings momentum strategy for each country in our sample: From January 1995 to December 2008, we rank stocks within each country on the basis of the change in their Type equation here. consensus 1-year-ahead (FY1) earnings forecast at the end of each month, scaled by price. If analyst forecasts are not revised in a given month, the earnings forecast revision from month $t$ to $t-1$ is zero for that stock. We follow Hong et al. [2003] to compute the cumulative price-deflated revision in analyst earnings forecasts $\left(\operatorname{Rev}_{i, t}\right)$ as a measure of earnings momentum.

We use both 3- and 6-month ranking periods to form the analyst forecast revision. The forecast revision over the past 3 months for firm $i$ in month $t$ is defined as: 


$$
\operatorname{Rev}_{i, t}=\sum_{j=0}^{2} \frac{\operatorname{Rev}_{i, t-j}}{P_{i, t-j-1}}
$$

where $R e v_{i, t}$ is the change in analyst earnings forecasts in month $t$ for firm $i$; and $P_{i, t}$ is the adjusted stock price for stock $i$ in month $t$.

Hong et al. [2003] document that in earnings announcement months, analysts' earnings forecasts switch to the new fiscal year after the announcement, and the FY1 estimate in earnings announcement months recorded on $\mathrm{I} / \mathrm{B} / \mathrm{E} / \mathrm{S}$ could represent forecasting for the next fiscal year, rather than the current fiscal year. To ensure that changes in earnings forecasts represent the difference between two consecutive forecasts for the same fiscal year, we adopt the methodology of Hong et al. [2003], as follows: If the announcement date occurs prior to the date on which $\mathrm{I} / \mathrm{B} / \mathrm{E} / \mathrm{S}$ compiles the mean estimate in month $t, \operatorname{Rev}_{i, t}$ is defined as the mean FY1 estimate in month $t$ minus its mean FY2 estimate in month $t$-1. On the other hand, if the announcement occurs after I/B/E/S compiles the mean estimate for that month, $\operatorname{Re} v_{i, t}$ is still defined as the difference between month $t$ and $t$-1's mean FY1 estimates, but $\operatorname{Re} v_{i, t+1}$ is defined as the mean FY1 estimate in month $t+1$ minus the mean FY2 estimate in month $t$.

We then group the sample firms into quintiles according to their earnings forecast revision rank for each month within each country. The bottom quintile contains stocks with the most unfavorable analyst forecast revisions, while the top quintile includes the stocks with the most favorable analyst forecast revisions. We examine returns on these equally 
weighted portfolios over periods of 30, 60, and 120 trading days, starting from the first trading day of the first month following the analyst forecast revision.

We treat each earnings forecast revision as a single event. We then use event study methodology and compute the cumulative returns on stock prices after each earnings forecast revision. Returns on these portfolios are then computed as average cumulative returns of stocks in these portfolios. The earnings momentum portfolio (W-L) is a zero-cost portfolio that buys the favorable-revision portfolio and sells the unfavorable-revision portfolio in each month.

Jegadeesh and Titman [1993] skip 1 month prior to momentum trading to avoid bid-ask spread and stock price reversal in the very short-term. Because most earnings forecasts are made between the 10th and the 20th day of the month, we also skip about a half month when we initiate holding positions at the beginning of the following month. We report earnings momentum based only on 3-month ranking periods, as we find no significant difference in earnings momentum profits between 3-month and 6-month ranking periods.

Tables 3, 4, and 5 report average 30, 60, and 120 trading-day returns of the winner, the loser, and the winner-minus-loser earnings momentum portfolios for each country, respectively. Our results show that earnings momentum strategy generates positive profits for 40 out of 41 countries across all three holding periods, except Peru ( $-1.1 \%$ for 30 days and $0.8 \%$ for 60 days). The five countries that show the lowest earnings momentum profits in the 
30-day holding period are Peru (-1.1\%), Egypt (0.2\%), Taiwan (0.3\%), Argentina (0.5\%), and Brazil $(0.7 \%)$. The five countries that show the highest earnings momentum profits in the 30-day holding period are China (3.7\%), Australia (3.7\%), Finland (3.7\%), Thailand (3.6\%), and Indonesia (3.4\%). The earnings momentum profits rankings stay fairly stable in the subsequent trading periods. The five countries that show the lowest earnings momentum profits in the 60 -day holding period are Peru (-0.8\%), Turkey $(0.4 \%)$, Taiwan $(0.4 \%)$, Brazil (1.0\%), and United States (1.5\%). The five countries that show the highest earnings momentum profits in the 60-day holding period are Australia (6.2\%), Thailand (6.1\%), New Zealand (5.6\%), United Kingdom (5.2\%), and Finland (5.2\%). The five countries that show the lowest earnings momentum profits in the 120-day holding period are Turkey $(0.9 \%)$, Taiwan (1.0\%), Argentina (1.1\%), Peru (1.4\%), and United States (1.7\%). The five countries that show the highest earnings momentum profits in the 120-day holding period include New Zealand (10.2\%), Australia (10.0\%), Norway (9.6\%), Germany (9.2\%), and Thailand (9.1\%). The equally weighted country-average earnings momentum returns are $2.1 \%, 3.2 \%$, and $5.6 \%$ for the 30, 60, and 120 trading-day holding periods, respectively.

Earnings momentum returns primarily derive from price continuation of the most unfavorable forecast-revision stocks, rather than the most favorable forecast-revision stocks. Longing the equally weighted country-average winner portfolios generates $0.3 \%, 0.8 \%$ and $1.1 \%$ returns for the 30,60 , and 120 trading-day periods, respectively, whereas shorting the 
equally weighted country-average loser portfolios generates $1.7 \%, 2.4 \%$, and $4.5 \%$ returns for the 30,60 , and 120 trading-day periods, respectively. A higher degree of price continuation in the most unfavorable forecast-revision stocks is also a widespread international phenomenon. In the 120 trading-day holding period, 28 of 41 countries show more than $50 \%$ of earnings momentum profits derived from shorting the bottom-quintile portfolio.

\section{Determinants of Cross-Country Earnings Momentum: Regression Analysis}

Following Chui et al. [2010], we examine the determinants of cross-country variation in earnings momentum profitability. Earnings momentum profits are regressed on IDV, UAI, and other determinants.

$$
E^{E m o m}{ }_{i t}=\alpha_{0}+\beta_{1} I D V_{i}+\beta_{2} U A I_{i}+F_{i} \gamma_{1}+A_{i t} \gamma_{2}+\varepsilon_{i t}
$$

where Emom $_{i t}$ is the average 120 trading-day return on the earnings momentum portfolio in country $i$ in year $t$. IDV $V_{i}$ is the individualism index of country $i$ and $U A I_{i}$ is the UAI of country $i . F_{i}$ and $A_{i t}$ are vectors of explanatory variables that are constant or updated annually, respectively. Details of the explanatory variables are provided in Appendix 1. We use the Fama-MacBeth [1973] procedure to estimate the regressions. We control for heteroskedasticity and autocorrelation using the Newey and West [1994] method in calculating the t-statistics of the averages of time-series estimates from these year-by-year, cross-sectional regressions. 
We first examine the relation between the two cultural variables and earnings momentum profits. The results from the Fama-MacBeth [1973] regressions reported in Panel A of Table 6 show that both IDV and UAI are significantly related to earnings momentum profits. Earnings momentum and IDV have a positive relationship, significant at the $1 \%$ level $(\mathrm{t}$-stat $=3.04)$. Earnings momentum and UAI are negatively related, significant at the $1 \%$ level $(\mathrm{t}$-stat $=-3.58)$. In addition, we follow Chui et al. [2010] and include other cross-country explanatory variables to explain cross-country variations in earnings momentum profits. These explanatory variables are classified as firm characteristics, financial market development, and macroeconomic variables. We examine in the subsections below the effect of these variables on earnings momentum returns.

\subsection{FIRM CHARACTERISTICS}

A number of behavioral studies examine the effect of firm characteristics on earnings momentum. We describe these cross-sectional determinants and examine whether cross-country variation in these variables explains earnings momentum profits and whether this variation affects the explanatory power of our cultural measures-IDV and UAI.

Several variables are used to proxy for the effect of speed of information flow and information uncertainty on the cross-sectional variation of momentum returns at the stock level rather than at the country level. These variables are examined at the country level by Chui et al. [2010]. Since Zhang [2006] shows that these variables are able to explain the 
variation of momentum profits, we employ them to examine their explanatory power with respect to earnings momentum. These variables include stock turnover $(\operatorname{LnV})$, average dispersion of analyst forecasts in a country (LnDisp), average number of analysts following a stock in a country ( $\operatorname{LnCov}$ ), median firm size in a market (LnSize), stock market price volatility (Volp), and cash flow growth rate volatility $($ VolFCF $)$. We also include price-tobook ratio $(P B)$. A detailed explanation of how these variables are collected and computed is set forth in Appendix 1.

Our regression results from Panel B, Table 6, reveal that the relation between IDV and earnings momentum remains significantly positive when these variables are controlled for in the regression $(\mathrm{t}-\mathrm{stat}=2.60)$. The coefficient on UAI remains significantly negative at the $1 \%$ level $(\mathrm{t}$-stat $=-3.38)$. However, none of these variables are correlated with earnings momentum profits.

\subsection{FINANCIAL MARKET DEVELOPMENT AND INSTITUTIONAL QUALITY}

Chui et al. [2010] suggest that the development of financial market and institutional quality might be correlated with informational efficiency because markets with greater integrity facilitate the flow of information and reduce transaction costs. Hence, we adopt variables used by Chui et al. [2010] to examine whether UAI, IDV, and earnings momentum profits are correlated when financial market development and institutional quality variables are controlled for. The financial market development variables include: the ratio of private 
credit-to-GDP (CreditGDP) as a measure of financial market development (suggested by Stulz and Williamson [2003]), capital flow restriction (Contr; a higher score signifies more restrictions) as a measure of the extent to which foreign institutions can invest in the market, the average common language dummy variable (Lang; a higher score indicates more common language) suggested by Chan et al. [2005], and the ratio of market capitalization of the stocks comprising the S\&P-IFC Investable Index to the market capitalization of the stocks comprising the S\&P-IFC Global Index in each country as a measure of stock market openness (Open), used by Bekaert et al. [2007].

Panel C, Table 6 indicates a significant correlation between IDV and earnings momentum profitability, when financial market development variables are considered. The relationship between UAI and earnings momentum remains significantly negative at the $1 \%$ level ( $\mathrm{t}$-stat $=3.09)$.

The institutional quality variables include the insider trading index (Insider; a higher score indicates less insider trading activity), which measures the prevalence of insider trading activity in a particular country, investor protection (Protection; a higher score means a higher level of protection) suggested by La Porta et al. [2006], the ICRG corruption index (Corruption; a higher value indicates a lower corruption level), and the ICRG political risk index (Political; a higher score indicates a lower political risk). Lesmond [2005] and Eleswarapu and Venkataraman [2006] find that corruption and political indices are correlated 
with country liquidity. To measure transaction costs, we include an estimate of trading costs (LnTran; a higher value indicates higher transaction costs), suggested by Chan et al. [2005].

Panel D, Table 6, shows that IDV is not related to earnings momentum when institutional quality variables are included in the regression. Consistent with previous models, UAI is negatively related to earnings momentum profits ( $\mathrm{t}$-stat $=-3.10)$. The level of insider trading is found to be negatively correlated with earnings momentum profits, significant only at the $10 \%$ level.

\subsection{MACROECONOMIC MODELS}

In this section, we examine the effect of macroeconomic variables on cross-country earnings momentum. Griffin et al. [2003] use macroeconomic variables such as GDP growth rate and inflation rate to explain the variation in momentum profits. We also use GDP growth rate $(G D P)$ and inflation growth rate (Inflation) to examine the extent to which cross-country differences in earnings-momentum profits can be explained by macroeconomic variables. Panel E, Table 6 indicates that the explanatory power of IDV with respect to cross-country earnings momentum profits remains statistically significant at the $1 \%$ level when macroeconomic variables are controlled for $(\mathrm{t}$-stat $=3.11)$. UAI also explains the variation in earnings momentum returns, significant at the $1 \%$ level $(\mathrm{t}$-stat $=-3.01)$. We also find that the rate of inflation growth explains earnings momentum returns, significant at the $10 \%$ level. 


\subsection{A COMPREHENSIVE MODEL}

It would be more desirable to examine earnings momentum profits and other explanatory variables collectively rather than in groups. However, because we have a relatively confined sample (limited number of countries), the degrees of freedom for such regression tests would be limited. In our comprehensive model, we include only those variables that have $10 \%$ or better significance in explaining earnings momentum returns. These variables include level of insider trading and inflation rate. We find that IDV and UAI remain significant at the $1 \%$ level in determining variations in earnings momentum returns. ${ }^{12}$

\section{Conclusions}

This paper investigates the relationship between individualism and uncertainty avoidance and the earnings momentum phenomenon. We build on the recent work by Chui et al. [2010], who examine the association between individualism and uncertainty avoidance and price momentum returns. We focus on earnings momentum, as this anomaly defies rational explanation. Fama [1998] notes that earnings momentum has survived robustness checks, including extension to more recent data, and suggests that the underlying determinants of earnings momentum represent an unsolved puzzle requiring further research.

\footnotetext{
${ }^{12} \mathrm{We}$ also examine the relationship between IDV, UAI, and price momentum and our results are consistent with Chui et al. [2010]. We find that individualism is positively related to price momentum profits but we find no relation between UAI and price momentum profits.
} 
Chui et al. [2010] urge researchers to examine cultural factors in the context of earnings momentum.

Chui et al. [2010] document a significant positive relationship between individualism and price momentum returns, but these authors indicate a non-significant association with uncertainty avoidance. They suggest that the positive relationship likely obtains because investors in an individualistic, relative to collectivist, culture tend to underreact to public information and to overreact to private information. This overreaction and underreaction is a manifestation of overconfidence and self-attribution biases, the result of which is consistent with the price momentum anomaly. Relying on the same reasoning, we also predict and find a positive relationship between individualism and earnings momentum returns.

The non-significance indicated in Chui et al. [2010] between uncertainty avoidance and price momentum could be due to the diverse range of macroeconomic information that is incorporated in stock prices. Because there are so many, often conflicting, inputs to stock prices, individuals in a high uncertainty-avoidance culture might not be able to quickly identify changes in stock price trends, thus their uncertainty-avoidance response (e.g., to sell stocks) is delayed until the preponderance of information indicates a trend change that raises their anxiety level above the threshold of their narrow comfort range. On the other hand, investors in a low uncertainty-avoidance culture will naturally delay their avoidance reaction, as they are quite tolerant of uncertainty and hold a comfort threshold that has a fairly wide 
range. Hence, for different reasons, there is an underreaction to price changes in both high and low uncertainty-avoidance cultures, the result of which perpetuates the price momentum phenomenon and explains the non-significant results of Chui et al. [2010].

In the current study, we hypothesize and find a negative relationship between uncertainty avoidance and earnings momentum. This is explained by the fact that earnings surprises are much easier and faster to detect than price surprises, because the range of inputs is narrower. As suggested by Chan et al. [1996], price momentum is a result of investor underreaction to broad economic information and earnings momentum is a result of investor underreaction to company-specific earnings information. Our results appear to support this line of reasoning.

Nevertheless, our results do not necessarily rule out competing theories or explanations. For example, individualism and uncertainty avoidance could potentially capture other behavioral biases. Future research in this area should also examine how uncertainty avoidance influences stock returns on a large pool of event-based market anomalies, particularly on those events that incorporate a large element of surprise, uncertainty, and ambiguity, such as post-IPO performance, mergers and acquisitions and dividend omissions.

To our knowledge, this is the first study that investigates the association between cultural factors and earnings momentum profits. The findings reported herein can help researchers and practitioners to better understand the earnings momentum anomaly. The 
results suggest that there is at least one unique underlying cultural factor separating the two momentum phenomena. Future research should examine other differentiating factors affecting earnings and price momentum. 


\section{REFERENCES}

ABARBANELL, J., and V. BERNARD. "Test of Analysts' Overreaction/Underreaction to Earnings Information as an Explanation for Anomalous Stock Price Behavior." Journal of Finance 47 (1992): 1181-207.

AVRAMOV, D., and T. CHORDIA. "Asset Pricing Models and Financial Market Anomalies." Review of Financial Studies 19 (2006): 1001-1040.

BALL, R., and E. BARTOV. "How Naive Is the Stock Market's Use of Earnings Information?" Journal of Accounting and Economics 21 (1996): 319-337.

BALL, R., and P. BROWN. "An Empirical Evaluation of Accounting Income Numbers." Journal of Accounting Research 6 (1968): 159-178.

BALL, R., S. P. KOTHARI, and R. L. WATTS. "Economic Determinants of the Relation Between Earnings Changes and Stock Returns.” The Accounting Review 68 (1993): 622-638.

BARBERIS, N., A. SHLEIFER, and R. VISHNY. “A Model of Investor Sentiment.” Journal of Financial Economics 49 (1998): 307-343.

BARTOV, E. "Patterns in Unexpected Earnings as an Explanation for Post-Announcement Drift." The Accounting Review 67 (1992): 610-622.

BEKAERT, G., C. R. HARVEY, C. LUNDBLAD, and S. SIEGEL. "Global Growth Opportunities and Market Integration.” Journal of Finance 62 (2007): 1081-1137.

BERNARD, V. L., and J. K. THOMAS. "Post-Earnings-Announcement Drift: Delayed Price Response or Risk Premium?” Journal of Accounting Research 27 (1989): 1-36.

BERNARD, V. L., and J. K. THOMAS. "Evidence that Stock Prices Do Not Fully Reflect the Implications of Current Earnings for Future Earnings." Journal of Accounting and Economics 13 (1990): 305-340.

BOOTH, G. G., J. KALLUNKI, and T. MARTIKAINEN. "Post Announcement Drift and Income Smoothing: Finnish Evidence.” Journal of Business Finance \& Accounting 23 (1996): 1197-1211.

BRENNAN, M. "A Perspective on Accounting and Stock Prices.” The Accounting Review 66 (1991): 67-79.

CHAN, K., V. COVRIG, and L. NG. "What Determines the Domestic Bias and Foreign Bias? Evidence from Mutual Fund Equity Allocations Worldwide." Journal of Finance 60 (2005): 1495-1534.

CHAN, L. K. C., N. JEGADEESH, and J. LAKONISHOK. "Momentum Strategies." The Journal of Finance 51 (1996): 1681-1713.

CHORDIA, T., and L. SHIVAKUMAR. "Momentum, Business Cycle, and Time-varying Expected Returns.” Journal of Finance 57 (2002): 985-1019. 
CHORDIA, T., and L. SHIVAKUMAR. "Earnings and Price Momentum." Journal of Financial Economics 80 (2006): 627-656.

CHOW, C. W., Y. KATO, and M. D. SHIELDS. "National Culture and the Preference for Management Controls: An Exploratory Study of the Firm-Labor Market Interface." Accounting, Organisations and Society 19 (1994): 381-400.

CHOW, C. W., M. D. SHIELDS, and Y. K. CHAN. "The Effects of Management Controls and National Culture on Manufacturing Performance: An Experimental Investigation." Accounting, Organisations and Society 16 (1991): 209-226.

CHUI, A. C. W., S. TITMAN, and K. C. WEI. "Individualism and Momentum around the World." Journal of Finance 65 (2010): 361-392.

CYERT, R. M., and J. G. MARCH. A Behavioral Theory of the Firm. Englewood Cliffs, NJ: Prentice-Hall, 1963.

DANIEL, K., D. HIRSHLEIFER, and A. SUBRAHMANYAM. "Investor Psychology and Security Market Under- and Overreactions.” Journal of Finance 53 (1998): 18391885.

DOYLE, J. T., R. J. LUNDHOLM, and M. T. SOLIMAN. "The Extreme Future Stock Returns Following I/B/E/S Earnings Surprises." Journal of Accounting Research 44 (2006): 849-887.

EDWARDS, W. "Conservatism in Human Information Processing." In: B. Kleinmutz, ed., Formal Representation of Human Judgment. New York: Wiley, 1968.

ELESWARAPU, V. R., and K. VENKATARAMAN. "The Impact of Legal and Political Institutions on Equity Trading Costs: A Cross-Country Analysis." Review of Financial Studies 19 (2006): 1081-1111.

ERTIMUR, Y., J. LIVNAT, and M. MARTIKAINEN. "Differential Market Reactions to Revenue and Expense Surprises." Review of Accounting Studies 8 (2003): 185-211.

FAMA, E. F. "Market Efficiency, Long-Term Returns, and Behavioral Finance." Journal of Financial Economics 49 (1998): 283-306.

FAMA, E. F., and J. D. MACBETH. "Risk, Return, and Equilibrium: Empirical Tests.” Journal of Political Economy 81 (1973): 607-636.

FOSTER, G., C. OLSEN, and T. SHEVLIN. "Earnings Releases, Anomalies, and the Behavior of Security Returns.” The Accounting Review 59 (1984): 574-603.

FRANCIS, J., R. LAFOND, P. M. OLSSON, and K. SCHIPPER. "Cost of Equity and Earnings Attributes." The Accounting Review 79 (2004): 967-1010.

FREEMAN, R. N., and S. TSE. "The Multiperiod Information Content of Accounting Earnings: Confirmations and Contradictions of Previous Earnings Reports.” Journal of Accounting Research 27 (1989): 49-79.

GERVAIS, S., and T. ODEAN. "Learning to Be Overconfident." The Review of Financial Studies 14 (2001): 1-27. 
GRIFFIN, J. M., X. JI, and J. S. MARTIN. "Momentum Investing and Business Cycle Risk: Evidence from Pole to Pole." Journal of Finance 58 (2003): 2515-2547.

HEINE, S. J., D. R. LEHMAN, H. R. MARKUS, and S. KITAYAMA. "Is There a Universal Need for Positive Self-Regard?” Psychological Review 106 (1999): 766-794.

HEW, D., L. SKERRATT, N. STRONG, and M. WALKER. "Post Earnings Announcement Drift: Some Preliminary Evidence for the UK." Accounting and Business Research 26 (1996): 283-293.

HIRSHLEIFER, D., and S. H. TEOH. "The Psychological Attraction Approach to Accounting and Disclosure Policy." Contemporary Accounting Research 26 (2009): 1067-1090.

HOFSTEDE, G. Culture's Consequences: International Differences in Work-Related Values. Beverly Hills: Sage Publications, 1980.

HOFSTEDE, G. Culture's Consequences: Comparing Values, Behaviors, Institutions, and Organizations across Nations. 2nd edition. Beverly Hills: Sage Publications, 2001.

HONG, D., C. M. LEE, and B. SWAMINATHAN. "Earnings Momentum in International Markets.” Working paper, Cornell University, 2003.

HONG, H., and J. C. STEIN. "A Unified Theory of Underreaction, Momentum Trading, and Overreaction in Asset Markets.” Journal of Finance 54 (1999): 2143-2184.

JACOB, J., T. LYS, and J. SABINO. "Autocorrelation Structure of Forecast Errors from Time-Series Models: Alternative Assessments of the Causes of Post-Earnings Announcement Drift." Journal of Accounting and Economics 28 (2000): 329-358.

JEGADEESH, N., and J. LIVNAT. "Post-Earnings-Announcement Drift: The Role of Revenue Surprises." Financial Analysts Journal 62 (2006): 22-34.

JEGADEESH, N., and S. TITMAN. "Returns to Buying Winners and Selling Losers: Implications for Stock Market Efficiency." Journal of Finance 48 (1993): 65-91.

JOHNSON, B., and W. C. SCHWARTZ. "Evidence that Capital Markets Learn from Academic Research: Earnings Surprises and the Persistence of Post-Announcement Drift.” Working paper, University of Arizona, 2001.

JONES, C. P., and R. H. LITZENBERGER. "Quarterly Earnings Reports and Intermediate Stock Price Trends.” Journal of Finance 25 (1970): 143-148.

JOY, M. O., R. H. LITZENBERGER, and R. W. MCENALLY. "The Adjustment of Stock Prices to Announcements of Unanticipated Changes in Quarterly Earnings.” Journal of Accounting Research 15 (1977): 207-225.

KACHELMEIER, S. J., and M. SHEHATA. "Internal Auditing and Voluntary Cooperation in Firms: A Cross-Cultural Experiment.” The Accounting Review. 72 (1997): 407-431.

KAGITCIBASI, C. "Individualism and Collectivism." Handbook of Cross-cultural Psychology. Boston: Allyn \& Bacon, 1997. 
KAHNEMAN, D., and A. TVERSKY. "Judgment under Uncertainty: Heuristics and Biases." Science 185 (1974): 1124-1131.

KOTHARI, S. P. "Capital Markets Research in Accounting." Journal of Accounting and Economics 31 (2001): 105-231.

LA PORTA, R., F. LOPEZ-DE-SILANES, and A. SHLEIFER. "What Works in Securities Laws?" Journal of Finance 61 (2006): 1-32.

LATANE, H. A., M. O. JOY, and C. P. JONES. "Quarterly Data, Sort-Rank Routines, and Security Evaluation.” The Journal of Business 43 (1970): 427-438.

LATANE, H. A., and C. P. JONES. “Standardized Unexpected Earnings-1971-77.” Journal of Finance 34 (1979): 717-724.

LEIPPOLD, M., and H. LOHRE. "International Price and Earnings Momentum." Working paper, Imperial College, London, 2008.

LESMOND, D. A. "Liquidity of Emerging Markets." Journal of Financial Economics 77 (2005): 411-452.

LIANG, L. "Post Earnings Announcement Drift and Market Participants' Information Processing Biases.” Review of Accounting Studies 8 (2003): 321-345.

LIU, W., N. STRONG, and X. XU. "Post Earnings Announcement Drift in the UK." European Financial Management 9 (2003): 89-116.

LIVNAT, J., and R. R. MENDENHALL. "Comparing The Post-Earnings Announcement Drift for Surprises Calculated from Analyst and Time Series Forecasts." Journal of Accounting Research 44 (2006): 177-205.

MANDE, V., and W. KWAK. "Do Japanese Analysts Overreact or Underreact to Earnings Announcements?" Abacus 32 (1996): 81-101.

MARKUS, H. R., and S. KITAYAMA. "Culture and the Self: Implications for Cognition, Emotion, and Motivation.” Psychological Review 98 (1991): 224-253.

MENDENHALL, R. R. “Arbitrage Risk and Post-Earnings-Announcement Drift.” Journal of Business 77 (2004): 875-894.

NARAYANAMOORTHY, G. "Conservatism and Cross-Sectional Variation in the PostEarnings Announcement Drift.” Journal of Accounting Research 44 (2004): 763-789.

NEWEY, W. K., and K. D. WEST. "Automatic Lag Selection in Covariance Matrix Estimation.” Review of Economic Studies 61 (1994): 631-653.

STUlZ, R. M., AND R. WILLIAMSON. "Culture, Openness, and Finance." Journal of Financial Economics 70 (2003): 313-349.

TRUONG, C. "Post Earnings Announcement Drift and the Roles of Drift-Enhanced Factors in New Zealand." Pacific-Basin Finance Journal 18 (2009): 139-157.

ZHANG, X. F. "Information Uncertainty and Stock Returns." Journal of Finance 61 (2006): 105-136. 
T A B L E 1

Summary Statistics - Sample Period: January 1995 December 2008

\begin{tabular}{|c|c|c|c|c|c|c|c|c|c|c|}
\hline \multirow[b]{2}{*}{ Country } & \multirow[b]{2}{*}{ IDV } & \multirow[b]{2}{*}{ UAI } & \multicolumn{2}{|c|}{ Datastream and CRSP (US) } & \multicolumn{3}{|c|}{$\begin{array}{c}\text { I/B/E/S and Datastream Matched } \\
\text { (US from CRSP) }\end{array}$} & \multicolumn{3}{|c|}{ All Criteria } \\
\hline & & & \# of Firms & $\begin{array}{l}\# \text { of Firms } \\
(\text { Price }>1)\end{array}$ & \# of Firms & $\begin{array}{c}\text { \# of } \\
\text { Announcements }\end{array}$ & $\begin{array}{l}\text { \# of Analyst } \\
\text { Forecasts }\end{array}$ & $\begin{array}{c}\text { \# of } \\
\text { Firms }\end{array}$ & $\begin{array}{c}\text { \# of } \\
\text { Announcements }\end{array}$ & $\begin{array}{l}\text { \# of Analyst } \\
\text { Forecasts }\end{array}$ \\
\hline Argentina & 46 & 86 & 95 & 95 & 75 & 509 & 5,261 & 75 & 480 & 3,717 \\
\hline Australia & 90 & 51 & 2,331 & 1,478 & 963 & 5,303 & 54,991 & 946 & 4,961 & 39,203 \\
\hline Austria & 55 & 70 & 133 & 133 & 105 & 677 & 7,322 & 105 & 650 & 5,281 \\
\hline Belgium & 75 & 94 & 219 & 217 & 151 & 1,125 & 12,247 & 148 & 1,082 & 8,857 \\
\hline Brazil & 38 & 76 & 474 & 463 & 164 & 999 & 10,450 & 162 & 942 & 7,450 \\
\hline Canada & 80 & 48 & 2,450 & 2,334 & 1,384 & 7,346 & 75,780 & 1,358 & 6,880 & 53,587 \\
\hline Chile & 23 & 86 & 187 & 185 & 116 & 759 & 7,962 & 116 & 711 & 5,662 \\
\hline China & 20 & 40 & 279 & 176 & 133 & 426 & 3,703 & 132 & 377 & 2,428 \\
\hline Denmark & 74 & 23 & 290 & 289 & 177 & 1,264 & 14,060 & 176 & 1,229 & 10,282 \\
\hline Egypt & 38 & 68 & 128 & 128 & 41 & 160 & 1,511 & 40 & 144 & 1,012 \\
\hline Finland & 63 & 59 & 188 & 184 & 166 & 1,333 & 14,542 & 166 & 1,288 & 10,554 \\
\hline France & 71 & 86 & 1,154 & 1,152 & 770 & 5,308 & 57,109 & 758 & 5,075 & 41,148 \\
\hline Germany & 67 & 65 & 1,166 & 1,166 & 845 & 5,160 & 55,239 & 843 & 4,962 & 39,727 \\
\hline Greece & 35 & 112 & 396 & 396 & 269 & 1,724 & 18,718 & 266 & 1,622 & 13,497 \\
\hline Hong Kong & 25 & 29 & 1,101 & 968 & 658 & 3,894 & 38,844 & 645 & 3,606 & 27,275 \\
\hline Hungary & 80 & 82 & 62 & 62 & 45 & 302 & 3,238 & 45 & 285 & 2,333 \\
\hline India & 48 & 40 & 1,318 & 1,317 & 559 & 3,167 & 31,580 & 554 & 2,926 & 22,014 \\
\hline Indonesia & 14 & 48 & 430 & 427 & 213 & 1,376 & 14,216 & 207 & 1,283 & 10,127 \\
\hline Ireland & 70 & 35 & 132 & 118 & 92 & 675 & 7,289 & 92 & 641 & 5,219 \\
\hline Israel & 54 & 81 & 787 & 781 & 117 & 597 & 5,939 & 114 & 541 & 4,136 \\
\hline Italy & 76 & 75 & 434 & 421 & 338 & 2,307 & 24,673 & 332 & 2,208 & 17,117 \\
\hline Japan & 46 & 92 & 4,718 & 4,718 & 3,478 & 24,054 & 246,309 & 3,418 & 22,838 & 173,702 \\
\hline Malaysia & 26 & 36 & 1,169 & 1,002 & 733 & 3,963 & 37,518 & 689 & 3,550 & 25,749 \\
\hline Mexico & 30 & 82 & 154 & 152 & 110 & 902 & 9,843 & 109 & 869 & 7,113 \\
\hline
\end{tabular}




\section{T A B L E 1 continued}

\begin{tabular}{|c|c|c|c|c|c|c|c|c|c|c|}
\hline Netherlands & 80 & 53 & 282 & 281 & 247 & 1,947 & 21,796 & 245 & 1,877 & 15,975 \\
\hline New Zealand & 79 & 49 & 219 & 172 & 123 & 881 & 9,635 & 123 & 858 & 7,002 \\
\hline Norway & 69 & 50 & 382 & 382 & 293 & 1,688 & 17,713 & 290 & 1,613 & 12,649 \\
\hline Peru & 16 & 87 & 121 & 111 & 53 & 291 & 3,056 & 53 & 272 & 2,169 \\
\hline Philippines & 32 & 44 & 254 & 236 & 113 & 826 & 9,017 & 111 & 788 & 6,535 \\
\hline Poland & 60 & 93 & 435 & 428 & 121 & 594 & 6,471 & 120 & 569 & 4,691 \\
\hline Portugal & 27 & 104 & 115 & 113 & 63 & 465 & 5,226 & 63 & 457 & 3,815 \\
\hline Singapore & 20 & 8 & 715 & 334 & 473 & 2,700 & 26,718 & 467 & 2,509 & 18,581 \\
\hline South Africa & 65 & 49 & 780 & 739 & 390 & 2,425 & 26,049 & 386 & 2,298 & 18,875 \\
\hline Spain & 51 & 86 & 208 & 208 & 163 & 1,435 & 16,271 & 162 & 1,406 & 11,949 \\
\hline Sweden & 71 & 29 & 711 & 690 & 357 & 2,434 & 26,555 & 353 & 2,337 & 19,314 \\
\hline Switzerland & 68 & 58 & 330 & 330 & 242 & 2,149 & 24,186 & 240 & 2,102 & 17,741 \\
\hline Taiwan & 17 & 69 & 1,727 & 1,471 & 845 & 4,467 & 42,200 & 822 & 4,015 & 28,802 \\
\hline Thailand & 20 & 64 & 581 & 578 & 439 & 2,540 & 26,083 & 434 & 2,411 & 18,402 \\
\hline $\begin{array}{l}\text { Turkey } \\
\text { United }\end{array}$ & 37 & 85 & 365 & 364 & 318 & 2,330 & 26,533 & 318 & 2,276 & 19,496 \\
\hline Kingdom & 89 & 35 & 3,378 & 3,370 & 2,205 & 14,001 & 144,432 & 2,168 & 13,153 & 102,164 \\
\hline United States & 91 & 46 & 21,532 & 21,240 & 13,128 & 64,515 & 672,482 & 12,532 & 59,810 & 481,808 \\
\hline Total & & & 51,930 & 49,409 & 31,275 & 179,018 & $1,862,767$ & 30,383 & 167,901 & $\mathbf{1 , 3 2 7 , 1 5 8}$ \\
\hline
\end{tabular}

This table reports summary statistics for the 41 countries in our sample for the period January $1995-$ December 2008 . We require each country in our sample to have both Hofstede's individualism index (IDV) and uncertainty-avoidance index (UAI). We obtain stock price data from Datastream International for 40 out of 41 countries. The data for the US are obtained from CRSP. We obtain earnings announcements data from I/B/E/S. We compute logarithmic returns from the price data and match Datastream and CRSP data with I/B/E/S data. The Datastream and CRSP heading reports number of firms with price data and number of firms with price data greater than 1 in local currency for all international markets and the US. The I/B/E/S and Datastream-matched heading reports the number of firms in Datastream for which earnings announcements data are available in I/B/E/S. Similarly, the I/B/E/S and CRSP heading reports the number of firms in CRSP for which earnings announcements data are available in I/B/E/S. The All Criteria heading reports I/B/E/S and Datastream/CRSP matched sample firms, excluding firms with stock price less than 1 in local currency and if analyst forecast revisions are greater than 50-times the current stock price (in local currency) in each month. Further, each country must have at least 30 stocks with return observations during the sample period. This table also reports IDV and UAI. The number of firms (\# of firms) is the total number of stocks for each country; the number of earnings announcements (\# of announcements) and the number of analyst forecast revisions (\# of analyst forecasts) are the total number of earnings releases and the number of times analysts reviewed the earnings per share for each country recorded by I/B/E/S, respectively. 
T A B L E 2

Spearman Rank Correlations - Sample Period: January 1995 December 2008

\begin{tabular}{|c|c|c|c|c|c|c|c|c|c|c|c|c|c|c|c|c|c|c|c|c|}
\hline & IDV & UAI & $\mathrm{LnV}$ & $\begin{array}{l}\text { LnDis } \\
\mathrm{p}\end{array}$ & $\begin{array}{l}\text { LnC } \\
\text { ov }\end{array}$ & $\begin{array}{l}\mathrm{LnSi} \\
\text { ze }\end{array}$ & $\mathrm{Pb}$ & Volp & $\begin{array}{l}\text { VolFC } \\
\text { F }\end{array}$ & $\begin{array}{l}\text { Credit } \\
\text { GDP }\end{array}$ & $\begin{array}{l}\text { Lan } \\
\mathrm{g}\end{array}$ & $\begin{array}{l}\text { Ope } \\
\mathrm{n}\end{array}$ & $\begin{array}{l}\text { Cont } \\
\mathrm{r}\end{array}$ & $\begin{array}{l}\text { Corru } \\
\text { ption }\end{array}$ & $\begin{array}{l}\text { Inside } \\
\mathrm{r}\end{array}$ & $\begin{array}{l}\text { LnTra } \\
\mathrm{n}\end{array}$ & $\begin{array}{l}\text { Polit } \\
\text { ical }\end{array}$ & $\begin{array}{l}\text { Protec } \\
\text { tion }\end{array}$ & GDP & $\begin{array}{l}\text { Inflati } \\
\text { on }\end{array}$ \\
\hline IDV & 1 & -0.2 & 0.0 & -0.2 & 0.0 & 0.2 & 0.2 & -0.6 & 0.1 & 0.1 & 0.0 & 0.6 & 0.3 & 0.4 & 0.1 & -0.3 & 0.4 & 0.0 & -0.2 & 0.4 \\
\hline UAI & -0.2 & 1 & -0.1 & 0.3 & 0.0 & 0.1 & 0.0 & 0.0 & 0.0 & -0.3 & -0.4 & -0.2 & -0.4 & -0.5 & -0.5 & -0.2 & -0.4 & -0.1 & -0.3 & 0.2 \\
\hline $\mathrm{LnV}$ & 0.0 & -0.1 & 1 & -0.5 & 0.2 & 0.7 & -0.1 & 0.0 & -0.1 & 0.2 & -0.1 & 0.2 & 0.2 & -0.2 & 0.4 & -0.3 & -0.3 & -0.4 & -0.3 & -0.5 \\
\hline LnDisp & -0.2 & 0.3 & -0.5 & 1 & 0.0 & -0.4 & 0.1 & 0.4 & 0.0 & -0.5 & 0.0 & -0.3 & -0.4 & -0.4 & -0.2 & 0.5 & -0.2 & 0.4 & 0.4 & 0.6 \\
\hline LnCov & 0.0 & 0.0 & 0.2 & 0.0 & 1 & 0.4 & -0.2 & -0.1 & 0.1 & 0.1 & 0.0 & 0.2 & 0.2 & 0.2 & -0.1 & -0.4 & 0.0 & 0.2 & -0.3 & -0.1 \\
\hline LnSize & 0.2 & 0.1 & 0.7 & -0.4 & 0.4 & 1 & 0.1 & -0.3 & -0.3 & 0.4 & 0.1 & 0.4 & 0.2 & -0.2 & 0.5 & -0.4 & -0.3 & -0.1 & -0.4 & -0.4 \\
\hline $\mathrm{Pb}$ & 0.2 & 0.0 & -0.1 & 0.1 & -0.2 & 0.1 & 1 & 0.0 & -0.2 & 0.1 & 0.1 & 0.6 & 0.0 & 0.2 & 0.1 & 0.1 & 0.3 & 0.2 & 0.2 & 0.3 \\
\hline Volp & -0.6 & 0.0 & 0.0 & 0.4 & -0.1 & -0.3 & 0.0 & 1 & -0.1 & -0.6 & -0.1 & -0.4 & -0.4 & -0.3 & 0.0 & 0.6 & -0.2 & -0.1 & 0.6 & -0.1 \\
\hline VolFCF & 0.1 & 0.0 & -0.1 & 0.0 & 0.1 & -0.3 & -0.2 & -0.1 & 1 & -0.1 & -0.2 & 0.0 & 0.0 & 0.2 & -0.5 & 0.0 & 0.2 & -0.3 & -0.1 & 0.3 \\
\hline CreditGDP & 0.1 & -0.3 & 0.2 & -0.5 & 0.1 & 0.4 & 0.1 & -0.6 & -0.1 & 1 & 0.3 & 0.3 & 0.5 & 0.2 & 0.3 & -0.4 & 0.2 & 0.0 & -0.3 & -0.3 \\
\hline Lang & 0.0 & -0.4 & -0.1 & 0.0 & 0.0 & 0.1 & 0.1 & -0.1 & -0.2 & 0.3 & 1 & 0.1 & 0.3 & -0.2 & 0.6 & 0.3 & -0.2 & 0.3 & 0.5 & -0.1 \\
\hline Open & 0.6 & -0.2 & 0.2 & -0.3 & 0.2 & 0.4 & 0.6 & -0.4 & 0.0 & 0.3 & 0.1 & 1 & 0.2 & 0.4 & 0.1 & -0.3 & 0.5 & 0.2 & -0.1 & 0.1 \\
\hline Contr & 0.3 & -0.4 & 0.2 & -0.4 & 0.2 & 0.2 & 0.0 & -0.4 & 0.0 & 0.5 & 0.3 & 0.2 & 1 & 0.0 & 0.3 & -0.2 & 0.0 & 0.1 & 0.0 & -0.2 \\
\hline Corruption & 0.4 & -0.5 & -0.2 & -0.4 & 0.2 & -0.2 & 0.2 & -0.3 & 0.2 & 0.2 & -0.2 & 0.4 & 0.0 & 1 & -0.2 & -0.2 & 0.7 & 0.0 & -0.1 & 0.0 \\
\hline Insider & 0.1 & -0.5 & 0.4 & -0.2 & -0.1 & 0.5 & 0.1 & 0.0 & -0.5 & 0.3 & 0.6 & 0.1 & 0.3 & -0.2 & 1 & 0.2 & -0.2 & 0.0 & 0.3 & -0.4 \\
\hline LnTran & -0.3 & -0.2 & -0.3 & 0.5 & -0.4 & -0.4 & 0.1 & 0.6 & 0.0 & -0.4 & 0.3 & -0.3 & -0.2 & -0.2 & 0.2 & 1 & -0.1 & 0.0 & 0.7 & 0.3 \\
\hline Political & 0.4 & -0.4 & -0.3 & -0.2 & 0.0 & -0.3 & 0.3 & -0.2 & 0.2 & 0.2 & -0.2 & 0.5 & 0.0 & 0.7 & -0.2 & -0.1 & 1 & 0.1 & 0.0 & 0.0 \\
\hline Protection & 0.0 & -0.1 & -0.4 & 0.4 & 0.2 & -0.1 & 0.2 & -0.1 & -0.3 & 0.0 & 0.3 & 0.2 & 0.1 & 0.0 & 0.0 & 0.0 & 0.1 & 1 & 0.3 & 0.2 \\
\hline GDP & -0.2 & -0.3 & -0.3 & 0.4 & -0.3 & -0.4 & 0.2 & 0.6 & -0.1 & -0.3 & 0.5 & -0.1 & 0.0 & -0.1 & 0.3 & 0.7 & 0.0 & 0.3 & 1 & 0.2 \\
\hline Inflation & 0.4 & 0.2 & -0.5 & 0.6 & -0.1 & -0.4 & 0.3 & -0.1 & 0.3 & -0.3 & -0.1 & 0.1 & -0.2 & 0.0 & -0.4 & 0.3 & 0.0 & 0.2 & 0.2 & 1 \\
\hline
\end{tabular}

This table presents the unconditional correlations between the variables used in the cross-country momentum regressions. The highly correlated variables' Spearman rank correlations are shown in bold (correlation greater than 0.5 ). 
T A B L E 3

Profitability of Earnings Momentum Strategy - 30 Trading Days

\begin{tabular}{|c|c|c|c|c|c|c|c|c|c|}
\hline Country & Losers & Winners & $\mathbf{W}-\mathbf{L}$ & t-stat & Country & Losers & Winners & $\mathbf{W}-\mathbf{L}$ & t-stat \\
\hline Argentina & 0.002 & 0.007 & 0.005 & 2.066 & Japan & -0.002 & 0.015 & 0.017 & 7.062 \\
\hline Australia & -0.03 & 0.007 & 0.037 & 2.489 & Malaysia & -0.024 & -0.002 & 0.022 & 5.975 \\
\hline Austria & -0.026 & 0.006 & 0.032 & 2.235 & Mexico & -0.015 & 0.011 & 0.027 & 6.015 \\
\hline Belgium & -0.016 & 0.003 & 0.019 & 1.333 & Netherlands & -0.017 & 0.004 & 0.021 & 7.371 \\
\hline Brazil & 0.003 & 0.01 & 0.007 & 1.54 & New Zealand & -0.019 & 0.009 & 0.028 & 0.768 \\
\hline Canada & -0.022 & 0.001 & 0.023 & 2.23 & Norway & -0.029 & 0.001 & 0.031 & 0.803 \\
\hline Chile & -0.018 & -0.004 & 0.014 & 2.43 & Peru & -0.007 & -0.019 & -0.011 & 1.614 \\
\hline China & -0.066 & -0.029 & 0.037 & -0.99 & Philippines & -0.03 & -0.017 & 0.012 & 7.14 \\
\hline Denmark & -0.02 & 0.006 & 0.026 & -0.833 & Poland & -0.021 & 0.001 & 0.022 & 8.276 \\
\hline Egypt & -0.005 & -0.002 & 0.002 & -0.23 & Portugal & -0.005 & 0.007 & 0.012 & 8.496 \\
\hline Finland & -0.024 & 0.013 & 0.037 & 6.393 & Singapore & -0.028 & -0.001 & 0.026 & 0.141 \\
\hline France & -0.023 & 0.003 & 0.026 & 7.22 & South Africa & -0.013 & 0.015 & 0.028 & 0.211 \\
\hline Germany & -0.037 & -0.009 & 0.028 & 8.183 & Spain & -0.001 & 0.012 & 0.013 & 0.379 \\
\hline Greece & -0.012 & 0 & 0.012 & 7.002 & Sweden & -0.019 & 0.006 & 0.025 & 0.289 \\
\hline Hong Kong & -0.031 & -0.002 & 0.028 & 7.686 & Switzerland & -0.012 & 0.011 & 0.022 & 0.401 \\
\hline Hungary & -0.011 & 0.012 & 0.023 & 7.647 & Taiwan & -0.014 & -0.012 & 0.003 & 16.684 \\
\hline India & -0.019 & -0.003 & 0.016 & 3.489 & Thailand & -0.043 & -0.006 & 0.036 & 20.232 \\
\hline Indonesia & -0.01 & 0.025 & 0.034 & 3.93 & Turkey & 0.026 & 0.033 & 0.007 & 23.473 \\
\hline Ireland & -0.016 & 0.007 & 0.022 & 4.234 & United Kingdom & -0.027 & 0.003 & 0.03 & 10.118 \\
\hline Israel & -0.028 & -0.012 & 0.016 & 5.799 & United States & 0.012 & 0.023 & 0.011 & 8.358 \\
\hline Italy & -0.01 & 0.01 & 0.021 & 5.893 & & & & & \\
\hline
\end{tabular}

This table reports the profitability of the earnings momentum strategy for the 41 countries in our sample. At the end of each month from January 1995 through December 2008, stocks in each country are ranked on the basis of their past change in consensus analyst earnings forecasts, which is measured by cumulative price-deflated revisions over the past 3 months. Stocks are then assigned to quintile portfolios and equal-weighted returns are computed for each portfolio. The bottom $20 \%$ is assigned to the loser portfolio and the top $20 \%$ to the winner portfolio in each month. These equally weighted portfolios are held for 30 trading days from the first trading day of the first month following the analyst forecast revision. Returns on these portfolios are computed as average cumulative returns of stocks in these portfolios. The earnings momentum portfolio (W-L) is a zero-cost portfolio that buys the favorable revision portfolio and sells the unfavorable revision portfolio in each month. 
T A B L E 4

Profitability of Earnings Momentum Strategy - 60 Trading Days

\begin{tabular}{|c|c|c|c|c|c|c|c|c|c|}
\hline Country & Losers & Winners & $\mathbf{W}-\mathbf{L}$ & t-stat & Country & Losers & Winners & $\mathbf{W}-\mathbf{L}$ & t-stat \\
\hline Argentina & -0.006 & 0.018 & 0.024 & 7.109 & Japan & -0.001 & 0.022 & 0.023 & 10.736 \\
\hline Australia & -0.059 & 0.003 & 0.062 & 7.746 & Malaysia & -0.029 & -0.004 & 0.025 & 12.206 \\
\hline Austria & -0.041 & 0.008 & 0.049 & 2.044 & Mexico & -0.016 & 0.018 & 0.034 & 6.196 \\
\hline Belgium & -0.022 & 0.009 & 0.032 & 2.394 & Netherlands & -0.021 & 0.009 & 0.03 & 4.823 \\
\hline Brazil & 0.004 & 0.013 & 0.01 & 3.02 & New Zealand & -0.034 & 0.022 & 0.056 & 4.85 \\
\hline Canada & -0.035 & -0.001 & 0.033 & 3.9 & Norway & -0.051 & 0.001 & 0.052 & 4.228 \\
\hline Chile & -0.025 & -0.008 & 0.017 & 3.108 & Peru & -0.019 & -0.027 & -0.008 & 3.751 \\
\hline China & -0.086 & -0.05 & 0.036 & 5.29 & Philippines & -0.045 & -0.021 & 0.024 & 5.244 \\
\hline Denmark & -0.027 & 0.019 & 0.046 & 4.401 & Poland & -0.03 & -0.003 & 0.026 & 4.733 \\
\hline Egypt & 0.006 & 0.027 & 0.02 & 3.593 & Portugal & -0.008 & 0.016 & 0.024 & 4.68 \\
\hline Finland & -0.029 & 0.023 & 0.052 & 3.768 & Singapore & -0.046 & -0.003 & 0.043 & 6.095 \\
\hline France & -0.033 & 0.006 & 0.039 & 3.181 & South Africa & -0.021 & 0.022 & 0.043 & 8.366 \\
\hline Germany & -0.068 & -0.021 & 0.047 & 4.586 & Spain & 0.004 & 0.025 & 0.022 & 10.104 \\
\hline Greece & -0.003 & 0.014 & 0.016 & 5.292 & Sweden & -0.027 & 0.009 & 0.036 & 5.506 \\
\hline Hong Kong & -0.041 & -0.002 & 0.039 & 1.621 & Switzerland & -0.01 & 0.023 & 0.033 & 6.087 \\
\hline Hungary & -0.009 & 0.027 & 0.036 & 1.397 & Taiwan & -0.01 & -0.006 & 0.004 & 7.481 \\
\hline India & -0.025 & -0.006 & 0.019 & 2.324 & Thailand & -0.076 & -0.015 & 0.061 & -0.545 \\
\hline Indonesia & -0.006 & 0.036 & 0.043 & 5.955 & Turkey & 0.067 & 0.072 & 0.004 & -0.091 \\
\hline Ireland & -0.028 & 0.02 & 0.048 & 7.482 & United Kingdom & -0.043 & 0.009 & 0.052 & 1.24 \\
\hline Israel & -0.042 & -0.022 & 0.02 & 9.487 & United States & 0.024 & 0.039 & 0.015 & 1.669 \\
\hline Italy & -0.019 & 0.018 & 0.037 & 11.534 & & & & & \\
\hline
\end{tabular}

This table reports the profitability of the earnings momentum strategy for the 41 countries in our sample. At the end of each month from January 1995 through December 2008, stocks in each country are ranked on the basis of their past change in consensus analyst earnings forecasts, which is measured by cumulative price-deflated revisions over the past 3 months. Stocks are then assigned to quintile portfolios and equal-weighted returns are computed for each portfolio. The bottom $20 \%$ is assigned to the loser portfolio and the top $20 \%$ to the winner portfolio in each month. These equally weighted portfolios are held for 60 trading days from the first trading day of the first month following the analyst forecast revision. Returns on these portfolios are computed as average cumulative returns of stocks in these portfolios. The earnings momentum portfolio (W-L) is a zero-cost portfolio that buys the favorable revision portfolio and sells the unfavorable revision portfolio in each month. 
T A B L E 5

Profitability of Earnings Momentum Strategy - 120 Trading Days

\begin{tabular}{|c|c|c|c|c|c|c|c|c|c|}
\hline Country & Losers & Winners & $\mathbf{W}-\mathbf{L}$ & t-stat & Country & Losers & Winners & $\mathbf{W}-\mathbf{L}$ & t-stat \\
\hline Argentina & 0.024 & 0.035 & 0.011 & 0.466 & Japan & -0.003 & 0.035 & 0.038 & 2.272 \\
\hline Australia & -0.104 & -0.004 & 0.1 & 1.504 & Malaysia & -0.059 & -0.023 & 0.036 & 1.541 \\
\hline Austria & -0.085 & 0.003 & 0.088 & 0.499 & Mexico & -0.011 & 0.058 & 0.069 & 1.051 \\
\hline Belgium & -0.034 & 0.017 & 0.051 & 13.03 & Netherlands & -0.036 & 0.027 & 0.063 & 5.574 \\
\hline Brazil & 0.015 & 0.051 & 0.036 & 14.75 & New Zealand & -0.055 & 0.047 & 0.102 & 6.552 \\
\hline Canada & -0.054 & -0.007 & 0.047 & 15.34 & Norway & -0.087 & 0.009 & 0.096 & 7.545 \\
\hline Chile & -0.049 & -0.009 & 0.04 & 4.044 & Peru & -0.032 & -0.018 & 0.014 & 0.107 \\
\hline China & -0.16 & -0.122 & 0.038 & 4.38 & Philippines & -0.093 & -0.053 & 0.04 & 0.837 \\
\hline Denmark & -0.045 & 0.033 & 0.078 & 5.107 & Poland & -0.06 & -0.036 & 0.024 & 1.642 \\
\hline Egypt & -0.009 & 0.051 & 0.06 & 4.051 & Portugal & -0.018 & 0.019 & 0.037 & 7.265 \\
\hline Finland & -0.04 & 0.044 & 0.084 & 4.653 & Singapore & -0.085 & -0.012 & 0.073 & 7.897 \\
\hline France & -0.06 & 0.019 & 0.079 & 5.124 & South Africa & -0.037 & 0.027 & 0.064 & 9.144 \\
\hline Germany & -0.136 & -0.044 & 0.092 & 0.95 & Spain & 0.019 & 0.052 & 0.033 & 9.535 \\
\hline Greece & -0.018 & 0.02 & 0.038 & 0.859 & Sweden & -0.053 & 0.01 & 0.063 & 13.57 \\
\hline Hong Kong & -0.081 & -0.019 & 0.062 & 2.374 & Switzerland & -0.02 & 0.041 & 0.061 & 8.406 \\
\hline Hungary & -0.041 & 0.027 & 0.068 & 6.695 & Taiwan & -0.058 & -0.048 & 0.01 & 9.664 \\
\hline India & -0.083 & -0.035 & 0.048 & 6.667 & Thailand & -0.137 & -0.046 & 0.091 & 12.75 \\
\hline Indonesia & -0.018 & 0.041 & 0.059 & 6.499 & Turkey & 0.145 & 0.154 & 0.009 & 2.235 \\
\hline Ireland & -0.049 & 0.032 & 0.081 & 2.431 & United Kingdom & -0.083 & 0.007 & 0.09 & 3.091 \\
\hline Israel & -0.084 & -0.036 & 0.048 & 2.184 & United States & 0.064 & 0.081 & 0.017 & 7.334 \\
\hline Italy & -0.041 & 0.027 & 0.068 & 3.646 & & & & & \\
\hline
\end{tabular}

This table reports the profitability of the earnings momentum strategy for the 41 countries in our sample. At the end of each month from January 1995 through December 2008, stocks in each country are ranked on the basis of their past change in consensus analyst earnings forecasts, which is measured by cumulative price-deflated revisions over the past 3 months. Stocks are then assigned to quintile portfolios and equal-weighted returns are computed for each portfolio. The bottom $20 \%$ is assigned to the loser portfolio and the top $20 \%$ to the winner portfolio in each month. These equally weighted portfolios are held for 120 trading days from the first trading day of the first month following the analyst forecast revision. Returns on these portfolios are computed as average cumulative returns of stocks in these portfolios. The earnings momentum portfolio (W-L) is a zero-cost portfolio that buys the favorable revision portfolio and sells the unfavorable revision portfolio in each month. 
T A B L E 6

Determinants of Earnings Momentum Profits across Countries: Results from Fama-MacBeth Regressions

\begin{tabular}{|c|c|c|c|c|c|c|}
\hline $\begin{array}{l}\text { EM } \\
120 \text { Days }\end{array}$ & $\begin{array}{l}\text { Panel A: } \\
\text { No Control }\end{array}$ & $\begin{array}{l}\text { Panel B: } \\
\text { Behavioral } \\
\text { Models }\end{array}$ & $\begin{array}{c}\text { Panel C: } \\
\text { Market } \\
\text { Development }\end{array}$ & $\begin{array}{c}\text { Panel D: } \\
\text { Institutional } \\
\text { Quality }\end{array}$ & $\begin{array}{c}\text { Panel E: } \\
\text { Macroeconomi } \\
\text { c Models }\end{array}$ & $\begin{array}{c}\text { Panel F: } \\
\text { Comprehensive }\end{array}$ \\
\hline Intercept & $0.0623(5.17)$ & 0.1350 ( 1.99$)$ & $0.0755(5.88)$ & $0.0844(2.02)$ & $0.0595(4.00)$ & $0.0877(4.01)$ \\
\hline IDV & $0.0004(3.04)$ & $0.0005(2.60)$ & $0.0006(2.65)$ & $0.0001(0.87)$ & $0.0004(3.11)$ & $0.0004(2.56)$ \\
\hline UAI & $-0.0004(-3.58)$ & $-0.0003(-3.38)$ & $-0.0005(-3.09)$ & $-0.0005(-3.10)$ & $-0.0003(-3.01)$ & $-0.0004(-3.98)$ \\
\hline $\mathrm{LnV}$ & & $-0.0013(-0.85)$ & & & & \\
\hline LnDisp & & $0.0009(0.49)$ & & & & \\
\hline LnCov & & $-0.0016(-0.13)$ & & & & \\
\hline LnSize & & $-0.0052(-1.52)$ & & & & \\
\hline Volp & & $0.0212(0.28)$ & & & & \\
\hline VolFCF & & $0.0006(0.09)$ & & & & \\
\hline $\mathrm{PB}$ & & $0.0015(0.19)$ & & & & \\
\hline CreditGDP & & & $0.0000(-0.04)$ & & & \\
\hline Lang & & & $-0.0481(-0.88)$ & & & \\
\hline Open & & & $-0.0455(-1.58)$ & & & \\
\hline Contr & & & $0.0024(0.84)$ & & & \\
\hline Corruption & & & & $0.0014(0.33)$ & & \\
\hline Insider & & & & $-0.0220(-1.65)$ & & $-0.0194(-1.26)$ \\
\hline LnTran & & & & $-0.0015(-0.37)$ & & \\
\hline Political & & & & $0.0002(0.26)$ & & \\
\hline Protection & & & & $-0.0017(-0.30)$ & & \\
\hline GDP & & & & & $0.0003(0.16)$ & \\
\hline Inflation & & & & & $-0.0018(-1.87)$ & $-0.0018(-1.63)$ \\
\hline Min. \# of obs & & 35 & 36 & 36 & 36 & 36 \\
\hline Max. \# of obs & & 39 & 39 & 39 & 39 & 39 \\
\hline Med. \# of obs & & 37 & 39 & 39 & 39 & $\begin{array}{l}39 \\
6 \%\end{array}$ \\
\hline Adj R-sqr & $3.2 \%$ & $3.2 \%$ & $8.1 \%$ & $7.5 \%$ & $6.4 \%$ & \\
\hline
\end{tabular}

In this table, the 120 trading-day cumulative returns on country-specific earnings-momentum portfolios are regressed on Hofstede's individualism index (IDV) and uncertainty-avoidance index (UAI) and other explanatory variables. Panel A reports the regression results on IDV and UAI. Panel B reports results related to a set of variables suggested by behavioral momentum models. These variables include the natural logarithm of stock turnover (LnV), the natural logarithm of the dispersion of analyst forecasts (LnDisp), the natural logarithm of analyst coverage (LnCov), the logarithm of median firm size (LnSize), the average price-to-book ratio ( $\mathrm{Pb}$ ), stock market price volatility (Volp), and cash flow growth rate volatility (VolFCF). Panel $\mathrm{C}$ shows results related to a set of proxies for financial market development. These proxies are total private credit expressed as a ratio of GDP (CreditGDP), average common language dummy variable (Lang), the ratio between monthly market value of the S\&P-IFC Market Index and the monthly market value of the S\&P-IFC Investable Index (Open), and an index on control of capital flows (Contr). Panel D reports results for a set of variables related to institutional quality. This set of variables includes the insider index (Insider, a higher score indicates that insider trading is less prevalent), the ICRG corruption index (Corruption, a higher value indicates a lower corruption level), the ICRG political risk index (Political), the natural logarithm of the transaction cost index (LnTran), and the investor protection index (Protection). Panel E reports results related to a set of macroeconomic variables. These variables include nominal GDP growth rate (GDP) and inflation growth rate (Inflation). Panel F reports results from the comprehensive model. This table reports time-series averages of crosssectional OLS estimates of the coefficients. T-statistics are reported in parentheses. The Newey-West [1994] heteroskedasticity- and autocorrelation-consistent estimates of standard errors are used to compute the t-statistics. 


\section{Appendix}

\section{Variable}

\section{Stock Return Data}

US

Non-US

Earnings dates and analyst forecasts

\section{Explanatory variables}

Hofstede's individualism index (IDV)

Hofstede's uncertainty-avoidance index $(U A I)$

\section{Behavioral Variables}

Market trading volume (TV)

Average dispersion in analyst forecasts in a country

Average volatility of individual stocks in a market (Volp)

Volatility of growth of cash flows (VolFCF)

Median market capitalization in a country (Size)

Average number of analysts

following each stock in a country

Price-to-book ratio in a country $(\mathrm{Pb})$ $\underline{\text { Source }}$

CRSP

Datastream International

$\mathrm{I} / \mathrm{B} / \mathrm{E} / \mathrm{S}$

Hofstede and Geert [1980]

Hofstede and Geert [1980]

Datastream International

$\mathrm{I} / \mathrm{B} / \mathrm{E} / \mathrm{S}$

Datastream International

Datastream International

Datastream International

$\mathrm{I} / \mathrm{B} / \mathrm{E} / \mathrm{S}$

Datastream International

Arithmetic mean of each country's market-to-book ratio component of Datastream Global Index for each year from 1995 through 2008

\begin{abstract}
A higher score indicates a higher degree of individualism

A higher score indicates a higher degree of uncertainty avoidance
\end{abstract} ahead earnings forecast revision

Market trading turnover of the Datastream Global Index of a given country

Arithmetic mean of standard deviation of analyst forecasts for each earnings announcement in each country

Arithmetic mean of annualized standard deviation of $\log$ price changes for each country in each year from 1995 through 2008, calculated from Datastream monthly standard deviation of log stock price changes $*(12) 1 / 2$

Arithmetic mean of annualized standard deviation of $\log$ Free Cash Flow changes for each country in each year from 1995 through 2008, calculated from Datastream monthly standard deviation of log Free Cash Flow Growth * ( 12 ) $1 / 2$

Median of each country's market capitalization component of Datastream Global Index for each year from 1995 through 2008

Average number of analysts providing 1-year ahead earnings forecasts for a firm in each country 
Variable

$\underline{\text { Source }}$

\section{Financial Market Development Variables}

Index on capital flow restrictions (Contr)

Average common language dummy variable (Lang)

\section{Market Integrity Variables}

Prevalence of insider trading (Insider)

Investor protection index

(Protection)

Transaction costs index (Trans)
Ratio of total private credit-to-GDP
$($ CreditGDP)
Chan et al. [2005]

World Development Statistics Database, World Bank

Economic Freedom of the World Annual Report

Chan et al. [2005]

La Porta et. al. [2006]

ICRG

ICRG

ICRG

IMF

$\mathrm{IMF}$
Total private credit of a country, divided by the country's GDP in a given year

\begin{abstract}
A lower value indicates more restrictions. Arithmetic mean of Foreign Ownership/Investment Restrictions Index, Capital Controls Index and International Capital Market Controls Index for each country in each year from 2000 through 2007
\end{abstract}

An average score of common language dummy that equals 1 if countries $i$ and $j$ share a major language, 0 otherwise

Composite score of disclosure requirements of each country, the arithmetic mean of six categories: (1) prospectus; (2) director compensation; (3) shareholders; (4) inside ownership; (5) irregular contracts; and (6) transactions

A lower value indicates lower level of investor protection. Arithmetic mean of International Country Risk Guide's monthly investment profile index for each country in each year from 1995 through 2009

A lower value indicates higher political risks. Arithmetic mean of International Country Risk Guide's monthly political risk score for each country in each year from 1995 through 2009

A lower value indicates higher level of corruption. Arithmetic mean of International Country Risk Guide's monthly corruption index for each country in each year from 1995 through 2009

Transaction cost associated with trading foreign securities. Originally computed by Elkins-Sherry based on commissions, fees, and market-impact costs for the period September 1996 through December 1998

\section{Macroeconomic Variables Inflation growth (Inflation)}

Average annual consumer price index percent changes for each country in each year from 1995 through 2008

GDP growth $(G D P)$
Average nominal GDP growth for each country in each year from 1995 through 2008 